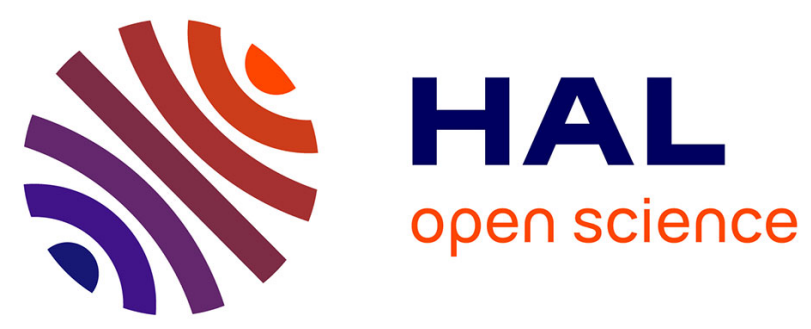

\title{
THE COMBINED EFFECT OF KrF-LASER IRRADIATION AND COPPER IONS ON THE SURVIVAL OF E.COLI CELLS
}

\author{
N. Zubrilin, N. Potapchenko, O. Savluk, M. Chernomorets
}

\section{- To cite this version:}

N. Zubrilin, N. Potapchenko, O. Savluk, M. Chernomorets. THE COMBINED EFFECT OF KrFLASER IRRADIATION AND COPPER IONS ON THE SURVIVAL OF E.COLI CELLS. Journal de Physique IV Proceedings, 1991, 01 (C7), pp.C7-249-C7-252. 10.1051/jp4:1991763 . jpa-00251006

\section{HAL Id: jpa-00251006 https://hal.science/jpa-00251006}

Submitted on 1 Jan 1991

HAL is a multi-disciplinary open access archive for the deposit and dissemination of scientific research documents, whether they are published or not. The documents may come from teaching and research institutions in France or abroad, or from public or private research centers.
L'archive ouverte pluridisciplinaire HAL, est destinée au dépôt et à la diffusion de documents scientifiques de niveau recherche, publiés ou non, émanant des établissements d'enseignement et de recherche français ou étrangers, des laboratoires publics ou privés. 


\title{
THE COMBINED EFFECT OF KrF-LASER IRRADIATION AND COPPER IONS ON THE SURVIVAL OF E.COLI CELLS
}

\author{
N.G. ZUBRILIN, N.G. POTAPCHENKO, O.S. SAVLUK and M.P. CHERNOMORETS \\ Kiev University, Vladimirskaya 64, 252017 Kiev-17, USSR
}

\begin{abstract}
E. Cali cells under the separated and combined action of the $\mathrm{KrF}$ laser $(\lambda=248 \mathrm{~nm})$ and copper ions has been studied. The synergistic effect has been observed at the doses of $10 \mathrm{~mJ} / \mathrm{cm}^{2}$. The evaluations of 1 ight reduction and absorbtion cross-sections for the E.Coli cells and also the probability of the cell inactivation after light quantum absorbtion are presented.
\end{abstract}

In the practice of water treatment the chemical methods of water disinfection are of the most wide usage. The physical methods, such as UV irradiation, electric field ets., are more ecologicaly pure, but their application is 1 imited by high energy demands. The promising results have been obtained when UV irradiation has been used together with the oxidants - ozone, hidrogen peroxide, clorine and its compounds $[1,2]$.

UV irradiation causes a some of breakdowns in the bacterial cells, the most critical being the damages of nucleine acids and cell membranes. The permeability of the membranes may be increased, in particular for ions $[3,4]$.

In this work the separated and combined action of the UV irradiation Cexcimer $\mathrm{KrF}$ laser, $\lambda=248 \mathrm{~nm}$ and copper ions upon the E. Coli cells has been studied.

Bacterial suspension in the physiological solution with the density of $10^{-6} \mathrm{cel} 1 \mathrm{~s} / \mathrm{ml}$ has been prepared from the 18-hour culture of E. Coli 1257. Suspension has been placed into the quarts vessel of $10 \times 10 \times 45$ $\mathrm{mm}$. To obtain the homogeneous irradiation and variability of the dose, the laser beam has been broadened with a quarts lens. The large 
doses have been obtained by accumulation of a seqence of pulses. The maximal density of energy in a pulse has been equal to $4,7 \mathrm{~mJ} / \mathrm{cm}^{2}$, and the density of power $-315 \mathrm{~kW} / \mathrm{cm}^{2}$ with the pulse width of 15 ns. The directly measured 1 ight reduction cross-section $\operatorname{co}_{\alpha}$ of a cell $C$ scattering + absorbtion $J$ at $\lambda=248 \mathrm{~nm}$ has been equal to $4 \times 10^{-8}$ $\mathrm{cm}^{2}$, thus weakening the 1 ight on $1 \mathrm{~cm}$ distance at the cell concentration of $10^{\circ} \mathrm{cm}^{-3}$ for $4 \%$.

At the begining it has been found that in the range of power densities from 20 to $300 \mathrm{~kW} / \mathrm{cm}^{2}$ at the same dose equal to $4,7 \mathrm{~mJ} / \mathrm{cm}^{2} \mathrm{the}$ inactivation degree of the E. Coli cells does not change, what qualitatively corresponds to the Ref. [5] conclusions. The E. Coli cells differ in this way from chlorella, yeast and algae cells, for which the dependence of survival on the power of the UV irradiation has a pronounced threshold character [6].

Fig. 1 illustrates the dependence of the cell survival upon the dose

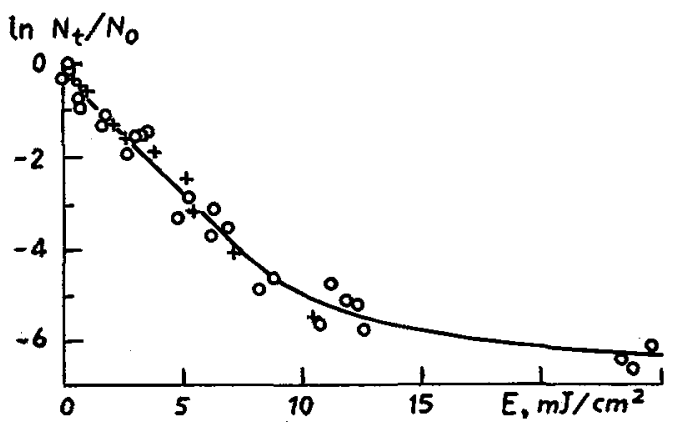

Fig.1. Survival of the E. Coli cells versus the dose of the laser irradiation.

of irradiation obtained in 6 runs of measurements. The results of single rum is marked with the crosses. The experimental data is approximated with the mean-square error of 0.3 . The slowdown of the inactivation rate at the doses over $10 \mathrm{~mJ} / \mathrm{cm}^{2}$ may be connected with the initial heterogenety of the population in its resistance to the UV irradiation, with the screening effects, and unhomogeneity of the 1 ight beam.

The combined action of the copper ions and the UV irradiation has been studied at the doses from 0,3 to $25 \mathrm{~mJ} / \mathrm{cm}^{2}$ with the contact time with copper ions equal to 60 minutes. Cuso solution has been added to suspension so that the concentration of CuIII ions reached 
$1 \mathrm{mg} / \mathrm{l}$. Such a concentration causes $18 \%$ inactivation of cells in 60 min. The experiments have been performed in two variants. In the first one copper has been added immediately after the irradiation of the cells, in the second one suspension has been irradiated immediatel $y$ after copper has been added. To evaluate the results the ratio of calculated part of survivals $C T$ supposing the independant action of desinfectants against the experimental count (b) has been used [7]. If the combined action is enhanced, then $T / \mathcal{F}>1$.

The results of the joined action of the UV irradiation and copper ions are presented in the Table.

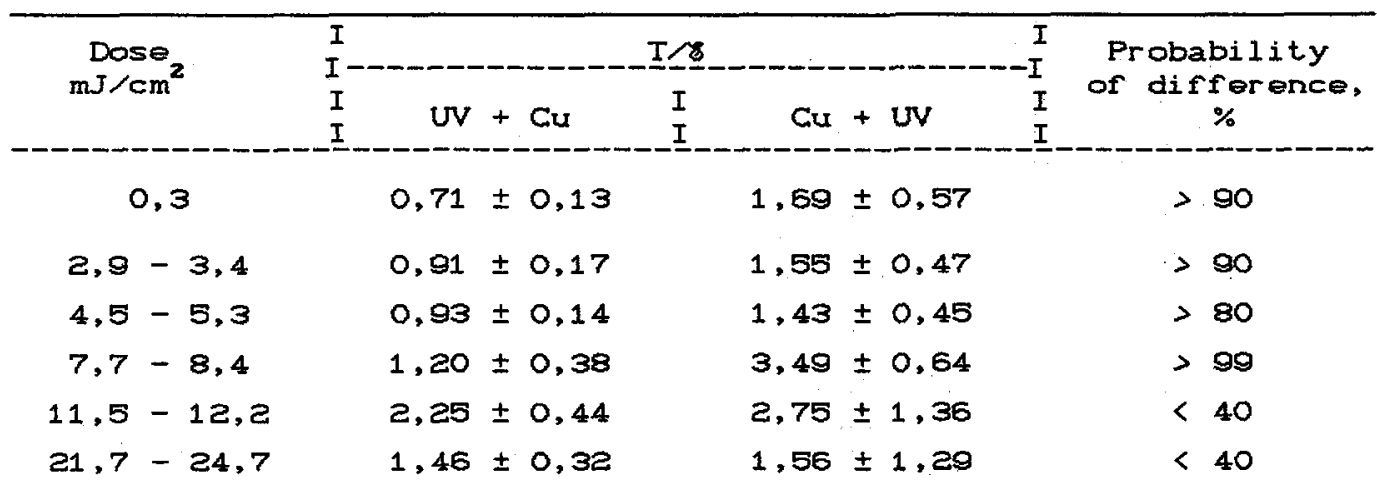

The data is averaged over 3 to 5 measurements. In the first variant (UV+Cu) at the low doses of irradiation the action of disinfectants is additive. The synergistic effect is observed in the first variant at the doses over $7 \mathrm{~m} / \mathrm{cm}^{2}$ and at all the doses in the second variant CCu+UV. It is interesting, that the both variants show the ma$x i m a l$ synergistic effect at a dose of $11-12 \mathrm{~mJ} / \mathrm{cm}^{2}$.

The absorbance cross-section of an E. Coli cell has been evaluated according to the transmission spectra recorded on the "Specord" spetrometer. At the wavel ength of $250 \mathrm{~nm}$ this value was of $10^{-0} \mathrm{~cm}^{2}$ of order.

The linear part of the dose dependence CFig. 13 corresponds to the exponential dependence of the number of survivals upon the dose: $N_{t}=$ $\mathrm{N}_{\mathrm{a}} \exp ^{(-k E)}$, or in the differential form:

$$
d N_{t}=-N_{t} \cdot k \cdot d E \text {. }
$$

where $k$ - is a slope of the linear part and $N_{0}$ is the initial number of the cells.

On the other hand, if the concentration of cells does not reduce the light through the thickness of suspension considerably, a number of 
light quantums absorbed by the living cells is

$$
d n=\frac{\sigma_{a} N_{t}}{h \nu} d E
$$

where hv is the energy of a quantum.

The ratio

$$
\alpha=\left|\frac{\mathrm{dn}}{d N_{t}}\right|=\frac{\sigma_{\alpha}}{\mathrm{kh \nu}}
$$

corresponds to the number of quantums, absorbed by the Iiving cell per one event of inactivation. The obtained experimental data show, that $\alpha \sim 10^{\circ}$ quantums/cell.

The equation (1) is valid only in a case, when the probability of cell inactivation does not depend on the number of quantums absorbed by the cell for the previous period. That is only in one of $10^{\circ} \mathrm{ab}-$ sobance acts the lethal damage occures; all the other damages are not lethal and do not affect the resistance of a cell to the UV irradiation. Among such damages there may be short-lived, corrected by the cell reparation system. They may assist the copper ions penetration into the cell and/or enhance their bactericidal effect. It is obvious, that the synergistic effect in this case may occure if the reparation time is large enough, for instance at high doses of UV irradiation. The effect must be more pronounced if the irradiated culture containes copper ions al ready.

CusO $_{4}$ solution exhibits a weak absorption in the $248 \mathrm{~nm}$ region, so it is possible, that in the second variant the changes of disinfectant have place, thus increasing its disinfecting abilities.

1/ Petranovskaya M.P. at al. Sanitariya i gigiena 12 (1986) 54 (In Russian.

a Leitao A. G. at al. Int. J. Radiat. Biol. 53 (1988) 477.

13/ Roshchupkin D.I. Photobiology of a living cell. Leningrad: "Nauka* (1975) 23 (In Russian).

4/ Vladimirov V. Yu. and Roshchupkin D.I. Biological action of the ultraviolet irradiation. Moscow: "Nauka" (1975) 31 (In Rassian).

S/ Avakyan C.M. at al. Doklady Akademi i Nauk ArmSSR 86 (1988) 32 (In Russian).

16/ Gavrilov A.G. at al. Doklady Akademii Nauk SSSR 239 (1978) 1238 (In Russian).

7/ Ragab-Depre N.J. Appl. and Envirom. Microbiol. 44 (1982) 555. 